\title{
Primary Intraosseous Meningioma Mimicking Osteosarcoma: Case Report
}

\section{Osteosarkomu Taklit Eden Primer Intraosseöz Menenjiyom: Olgu Sunumu}

Kryasettin ASIL ${ }^{1}$, Yakup Ersel AKSOY ${ }^{1}$, Can YALDIZ ${ }^{2}$, Zeynep KAHYAOGLU

${ }^{1}$ Sakarya Training and Research Hospital, Department of Radiology, Sakarya, Turkey

${ }^{2}$ Sakarya Training and Research Hospital, Department of Neurosurgery, Sakarya, Turkey

${ }_{3}^{3}$ Sakarya Training and Research Hospital, Department of Pathology, Sakarya, Turkey

Corresponding Author: Can YALDIZ / E-mail: drcanyaldiz@yahoo.com

\begin{abstract}
With an incidence rate of $15-20 \%$, meningiomas are one of the most common brain tumors among benign intracranial tumors. They are distributed as follows in intracranial localizations: parasagittal and falx (25\%), convexity (18\%), sphenoid wing (18\%), parasellar (12\%), posterior fossa (10\%), intraventricular (2\%), intraorbital (1\%), and extracranial (1\%). The most common extradural localizations are the paranasal sinuses, nasal cavity, skin, neck, glands, and intraosseous space. Intradiploic meningiomas are generally localized in the frontoparietal and orbital regions. Due to their low incidence and lack of adequate preoperative diagnostic testing, intradiploic meningiomas are generally mistaken for primary calvarial bone tumors and en plaque meningiomas. Our case was discussed here with literature findings since primary intradiploic meningioma is uncommon and poses diagnostic challenges.
\end{abstract}

KEYWORDS: Meningioma, Intraosseous, Hyperostosis

öz

Menenjiyomlar intrakraniyal yerleşimli olan iyi huylu tümörler içerisinde \%15-20 ile en sık görülen beyin tümörlerinden biridir. İntrakraniyal lokalizasyonlarına göre; parasagittal ve falks $\% 25$, konveksite $\% 18$, sfenoid kanat $\% 18$, parasellar $\% 12$, posterior fossa $\% 10$, intraventriküler $\% 2$, intraorbital \%1 ve ekstrakranial ise \%1 oranında görülür. Ekstradural yerleşim olarak paranazal sinüsler, nazal kavite, cilt, boyun, salgı bezleri, intraosseöz mesafe en sık görülen lokalizasyonlardır. İntradiploik menenjiyomlar genellikle frontoparietal ve orbital bölgelere lokalizedirler. Intradiploik menenjiyomlar, oldukça nadir görülmesi ve preoperatif yeterli tanısal tetkik olmaması nedeniyle genellikle primer kalvarial kemik tümörleri ve en-plak menenjiyomlarla karıştıııırlar. Primer intradiploik menenjiyom nadir görülmesi ve tanısal zorlukları sebebiyle burada literatür eşliğinde tartışıldı.

ANAHTAR SÖZCÜKLER: Menenjiyom, İntraosseöz, Hiperostozis

\section{INTRODUCTION}

Meningiomas account for $15-20 \%$ of intracranial tumors. They are distributed as follows in intracranial localizations: parasagittal and falx (25\%), convexity $(18 \%)$, sphenoid wing (18\%), parasellar (12\%), posterior fossa (10\%), intraventricular $(2 \%)$, intraorbital (1\%), and extracranial (1\%). The most common extradural localizations are the paranasal sinuses, nasal cavity, skin, neck, glands, and intraosseous space. Extradural meningioma was first reported by Winkler in 1904. Meningiomas without any dural connections are called ectopic meningiomas. Intradiploic meningiomas are mostly localized in the frontoparietal and orbital regions. The literature contains no reports clearly detailing how the preoperative diagnosis of primary intraosseous meningiomas should be made, and they are often mistaken for primary bone tumors and hyperostosis en plaque meningiomas (2, 7-9). Our case was presented here because of its rarity and discussed with literature findings due to lack of adequate diagnostic criteria in the literature.

\section{CASE REPORT}

A 64-year-old male patient was admitted to our clinic with pain and swelling on the right side of head that had started about 6 months ago and increased slowly. The patient's neurological and physical examination findings were normal. Radiological examination showed a sclerotic bone lesion causing a spicular periosteal reaction on the right frontotemporal region. As the lesion showed a spicular periosteal reaction, a lesion (Figure 1A-D) that does not destroy the bone structure in T1- and T2-weighted images but causes decreased signal and hypointense periosteal reaction in the bone was searched for on contrast cranial MR examination performed to exclude malignancies, and dural thickening and contrast enhancement in this region were searched for on gadolinium T1-weighted images (Figure 1A-D). These findings were identified as indicative of calvarial metastasis or primary osteosarcoma. Three-phase total body bone scintigraphy showed perfusion, and blood pool scans showed increased activity consistent with hyperemia only in the right temporal- 
frontal region, with increased heterogeneous osteoblastic activity in the same region during the late phase. These findings were identified as indicative of a primary malignant bone lesion.

Based on such clinical and radiological findings, the patient was operated with a preliminary diagnosis of calvarial bone metastasis. Histopathological examination showed infiltrative tumoral tissue between cortical bone lamellae in sections sampled after decalcification. The tumor also invaded the peripheral striated muscle tissue. The tumor was made up of monotonous cells with eosinophilic cytoplasm, forming groups and solid islands, with round to oval vesicular nuclei, some of them containing distinct nucleoli with indistinct margins. Tumoral cells immunohistochemically stained with EMA, Vimentin and S-100 (pale). The patient was diagnosed with intradiploic meningioma in light of these data. Dural thickening was identified as indicative of reactional thickening rather than dural involvement (Figure 2A,B). The patient was discharged with no neurological deficits on postoperative day 3. The patient had no complaints at the 2-month clinical follow-up.
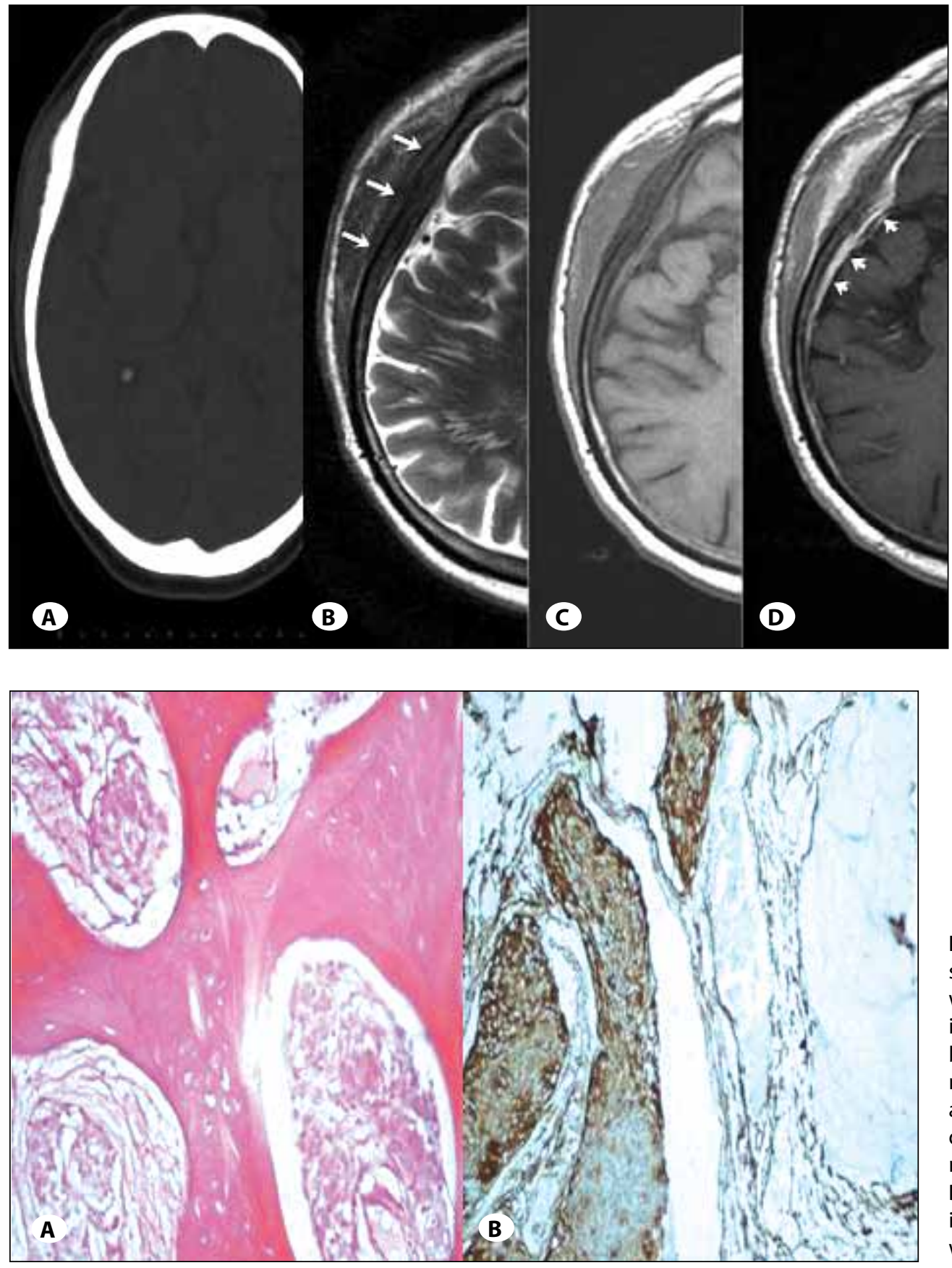

Figure 1: A) CT scan shows periosteal reaction and thickening at the right temporal bone.

B) Hypointense periosteal reaction on axial T2-weighted MR view. C) Hypointense periosteal reaction on axial T1-weighted MR view. D) Axial T1-weighted MR view after gadolinium infusion. Contrast enhancement that may be compatible with reactional perineoplastic edema or soft tissue is seen around the lesion. Thickening and contrast enhancement of the dura are noted.
Figure 2: A) The sections show monotonous tumor cells with eosinophilic cytoplasm infiltrating between cortical bone lamellae. The cells have round to oval vesicular nuclei and some of these contain distinct nucleoli with indistinct margins (H\&E x200).

B) Tumoral cells were immunohistochemically stained with EMA (EMA x400). 


\section{DISCUSSION}

The incidence of meningioma is $2.1 / 100000$ in the general population. The female to male incidence rate is $2: 1(7,8)$. Intradiploic meningiomas account for $2 \%$ of all meningiomas (7). Lang et al. (3) classified them into 3 types in order to prevent any confusion: purely extra-calvarial (type I), purely calvarial (type II), and calvarial with extracalvarial extension (type III). Our case fell into the type III classification.

The origin of primary intraosseous meningiomas remains unknown. Turner et al. have shown the rests of arachnoid cap cells at autopsy (5), while Azar-Kia et al. proposed that the rests of arachnoid cap cells remained between the sutures during embryogenic development $(1,4,6)$. The etiology of intraosseous meningiomas that develop in posttraumatic linear fractures can be explained by the same mechanism (7). Our case had no history of trauma.

The clinical findings of primary intraosseous meningiomas develop with the presence of mass. Clinical findings therefore vary according to the unique anatomic localization (7). X-ray, cranial tomography, and cranial MR are used as methods of radiological screening in diagnosing intradiploic meningioma. Radiological screenings have also found a mixed type showing both osteoblastic and osteoclastic activities (7). X-ray graphs have been identified as indicative of hyperostosis, irregular calcification, atypical vascular structures in the bone, and osteoblastic lesions, with hypodense areas as indicative of osteoclastic lesions. Osteoblastic and osteoclastic tumors have similarly been found on MR images. T1 images have shown a hypointens, and T2 images have shown a hyperintense mass (7). The radiological differential diagnosis of osteoblastic lesions should include metabolic diseases including osteoma, metastatic $\mathrm{Ca}$, hyperparathyroidism, meningioma, metastasis, and $A$ and $D$ hypervitaminosis $(4,6,7)$. The differential diagnosis of the osteoclastic lesion should include chondroma, chondrosarcoma, hemangioma, epidermal cyst, eosinophilic granuloma, metastasis and fibrous dysplasia $(6,7)$. Our case had no pathology other than diabetes mellitus controlled by oral antidiabetics.

Brain tomography can be used to best define the margins of meningiomas in the bone window and MR imaging can be used to identify adherent tissue involvement. Scintigraphy and PET-CT can be used for the differential diagnosis. Bone scintigraphy shows an increased metabolic activity of the bone region in question when positive, as in our case. The tumor is the cause of this increased metabolic activity, which can also be seen in arthrosis, infections and traumatic conditions (7).

Primary intradiploic meningiomas are typically benign lesions, and do not require treatment unless symptomatic. The primary choice for treatment is wide, total surgical removal and reconstruction (7). Radiological follow-up is recommended in subtotal removal. Options including adjuvant RT are recommended in recurrent and symptomatic cases. Our case underwent wide, total surgical excision.

\section{CONCLUSION}

Intraosseous meningiomas mimicking osteosarcomas and metastatic masses should also be considered in the differential diagnosis of masses in the calvarial bone.

\section{REFERENCES}

1. Azar-Kia B, Sarwar M, Marc JA, Schechter MM: Intraosseous menengioma. Neuroradiology 6:246-253,1974

2. Elder JB, Atkinson R, Zee CS, Chen TC: Primary intraosseous Menengioma. Neurosurg Focus 23:E13,2007

3. Lang FF, Macdonald OK, Fuller GN, DeMonte F: Primary extradural meningiomas: $A$ report on nine cases and review of literature from the era of computerized tomography scanning. J Neurosurg 93(6):940-950, 2000

4. Morison MC, Weis KL, Moskos MM: CT and MR appearance of a primary intraosseous Menengioma. J Comput Assist Tomogr 12:169-170,1988

5. Turner OA, Laird AT: Meningioma with traumatic etiology. Report of a case. J Neurosurg 24:96-98, 1966

6. Van Tassel P, Lee YY, Ayala A, Carrasco CH, Klima T: Intraosseous Menengioma of the sfenoid bone. Skeleteal Radiology 20(5):383-386,1991

7. Yaldız C, Ceylan D, Kızılçay G, Dilek FH: Osteoblastik kemik metastazını taklit eden primer intraosseos meningiom: Olgu Sunumu. Turk Norosir Derg 22(1):55-58,2012

8. Yener U, Bayrakli F, Vardereli E, Sav A, Peker S: Intradiploic meningioma mimicking calvarial metastasis: Case report. Turk Neurosurg 19(3):297-301,2009

9. Yarmish G, Klein MJ, Landa J, Lefkowitz RA, Hwang S: Imaging characteristics of primary osteosarcoma: Nonconventional subtypes. Radiographics 30(6):1653-1672,2010 